\title{
Phase complex model of ternary reciprocal system $\mathrm{Na}^{+}, \mathrm{Sr}^{2+} \| \mathrm{WO}_{4}{ }^{2-}, \mathrm{MoO}_{4}{ }^{2-}$
}

\author{
(C) Alexander V. Burchakov, ${ }^{+}{ }^{+}$Ivan K. Garkushin, Sergey N. Milov, and Irina P. Kalinina \\ Samara State Technical University. Molodogvardeyskaya St., 244. \\ Samara,443100.Russia.E-mail: turnik27@yandex.ru
}

\begin{abstract}
*Supervising author; ${ }^{+}$Corresponding author Keywords: computer model, 3D model, KOMPAS-3D, phase complex, ternary reciprocal system, tungstates, molybdates, continuous series of solid solutions, phase equilibria, crystallizing phase, monovariant equilibria.
\end{abstract}

\begin{abstract}
The paper presents the results of a theoretical study of the phase complex of a three-component reciprocal system consisting of sodium and strontium tungstates and molybdates. Previously, a literature review was conducted on data on phase equilibria in the condensed state of individual salts, binary faceting systems. In two $\mathrm{Na}_{2} \mathrm{MoO}_{4}-\mathrm{SrMoO}_{4}$ and $\mathrm{Na}_{2} \mathrm{WO}_{4}-\mathrm{SrWO}_{4}$ binary systems, a eutetic equilibrium is observed with the formation of solid phases corresponding to the system components, and in two other $\mathrm{Na}_{2} \mathrm{MoO}_{4}-$ $\mathrm{Na}_{2} \mathrm{WO}_{4}$ and $\mathrm{SrMoO}_{4}-\mathrm{SrWO}_{4}$ binary systems, one phase of a continuous series of solid solutions crystallizes. Based on the mathematical model of the molar balance, one can uniquely determine the quantities of reaction products, the molecular formulas of solid solutions, and the equations of chemical reactions for an arbitrary mixture of system components. This model represents a set of algebraic equations by which the balance is calculated. To build a 3D computer model, the paper presents the equations for the conversion of coordinates from barycentric to Cartesian. The model is implemented in concentration-temperature coordinates using the KOMPAS-3D program using experimental data on the system. The model is built in two interpretations: based on data on the faceting elements and on the basis of all available data about the system. Comparison of the two models makes it possible to evaluate the predictive ability carried out using 3D modeling. From this comparison, it was found that using the 3D model it is possible to conduct a preliminary a priori forecast of phase equilibria in order to identify the structure of phase diagrams at the qualitative and quantitative levels. The projection of the crystallization polytherm onto the square of the compositions is represented by two fields of solid solutions $-\mathrm{Na}_{2} \mathrm{Mo}_{\mathrm{x}} \mathrm{W}_{1-\mathrm{x}} \mathrm{O}_{4}$ and $\mathrm{SrMo}_{\mathrm{x}} \mathrm{W}_{1-\mathrm{x}} \mathrm{O}_{4}$. Isothermal and polythermal sections were constructed. The system implements di- and monovariant equilibria.
\end{abstract}

\section{References}

[1] I.K. Garkushin, I.M.Kondratyuk, G.E. Egortsev, M.A. Istomova. Theoretical and experimental methods of multicomponent systems research: study guide. Samara: Samara State Technical University. 2012. $125 \mathrm{p}$.with illustrations (russian)

[2] Thermal constants of substances. Handbook in 10 Vols. under the scientific guidance of academician V. P. Glushko and etc., Vol.10, part 1. Moscow: All-Union Institute of Scientific and Technical Information Computational Technology Institute, USSR Academy of Sciences. 1981. P.42. (russian)

[3] Thermal constants of substances. Data base. Institute of Thermophysics of Extreme States RAS Joint Institute of High Temperatures RAS. Faculty of chemistry, Moscow State University named after M. V. Lomonosov. [Electronic resource] URL: http://www.chem.msu.su/cgi-bin/tkv.pl?show=welcom.html (Accessed date 04.07.19).

[4] The Inorganic Material Database (AtomWork) aims to cover all basic crystal structure, $x$-ray diffraction, property and phase diagram data of inorganic and metallic materials from main literature sources. Yibin XU, Junko HOSOYA, Yuta SAKAIRI, Hiroyuk YAMASATO [Электронный ресурс] URL: https://crystdb.nims.go.jp/index_en.html (Дата обращения 04.07.19).

[5] K.I. Garkushin, M.V. Chugunova, A.V. Burdakov, S.N. Milov. The formation of continuous series of solid solutions in saline systems. The journal "News of Saratov University. Chemistry Series. Biology. Ecology." 2018. Vol.18. Vol.3. P.268-277. (russian)

[6] Yu.G. Petrosyan, E.V. Tkachenko, V.M. Zhukovsky. Phase diagrams $\mathrm{Na}_{2} \mathrm{MoO}_{4}-\mathrm{MMoO}_{4}(\mathrm{M}-\mathrm{Ca}$, Sr, Ba). ACADEMY OF SCIENCES OF USSR. Neorgan. materials. 1975. Vol.11. No.9. P.1618-1621. (russian) 
[7] M.V. Mokhosoev, F.P. Alekseev, V.I. Lutsyk. Diagrams of the state of molybdenum and tungstate systems. Handbook. Novosibirsk: Science. 1978. 319p. (russian)

[8] E.I. Getman. Isomorphic substitution in tungstate and molybdenum systems. Novosibirsk: Science. 1985. 214p. (russian)

[9] A.S. Trunin, I.K. Garkushin. The system $\mathrm{Na}, \mathrm{Sr} \| \mathrm{MoO}_{4}, \mathrm{WO}_{4}$. Ukr. chem. mag. 1978. Vol.43. No.12. P.1270-1272. (russian)

[10] A.V. Burchakov, E.M. Dvoryanova, I.M. Kondratyuk. Phase equilibria in the three-component mutual system $\mathrm{Li}, \mathrm{K} \| \mathrm{I}, \mathrm{CrO}_{4}$. Journal of neorgan. chemistry. 2015. Vol.60. No.8. P.1100-1109. (russian)

[11] I.K. Garkushin, M.A. Demina, A.V. Burchakov, E.M. Dvoryanova, M.A. Istomova, A.V. Kolyado. Methods of image and partition of multicomponent systems: study guide. Samara: Samara State Technical University. 2016. 352p. (russian)

[12] A.V. Burchakov, D.V. Timoshin, E.M. Egorova, I.M. Kondratyuk, and A.S. Kirsanov. Chemical and phase models of a ternary reciprocal system $\mathrm{Li}, \mathrm{K} \| \mathrm{F}, \mathrm{CrO}_{4}$. Butlerov Communications. 2018. Vol.55. No.7. P.37-51. DOI: 10.37952/ROI-jbc-01/18-55-7-37

[13] https://ascon.ru/

[14] M.S. Demin, A.V. Burchakov, and I.K. Garkushin. Phase complex of ternary system Li || $\mathrm{F}, \mathrm{VO}_{3}, \mathrm{WO}_{4}$. Butlerov Communications. 2015. Vol.42. No.6. P.91-95. DOI: 10.37952/ROI-jbc-01/15-42-6-91

[15] A.V. Burchakov, E.M. Dvoryanova, I.M. Kondratyuk. Phase equilibria in the three-component mutual system Li,K $\| \mathrm{I}, \mathrm{CrO}_{4}$. Journal of Neorgan. Chemistry. 2015. Vol.60. No.8. P.1100-1109. (russian)

[16] A.V. Burchakov, E.M. Egorova, I.M. Kondratyuk, Y.V. Moshensky. Phase equilibria in the system LiF-KI-KF- $\mathrm{K}_{2} \mathrm{CrO}_{4}$. Journal of Neorgan. Chemistry. 2018. Vol.63. No.7. P.909-920. (russian)

[17] A.S. Kirsanov, and A.V. Burchakov. Experimental study and modeling of phase transformations in a stable triangle NaF-KF-CsBr of quaternary reciprocal system $\mathrm{Na}, \mathrm{K}, \mathrm{Cs} \| \mathrm{F}, \mathrm{Br}$. Butlerov Communications. 2015. Vol.42. No.6. P.68-74. DOI: 10.37952/ROI-jbc-01/15-42-6-68

[18] A.V. Burchakov, E.M. Dvoryanova, and I.M. Kondratyuk. Liquid compound stratification details in quasi-ternary system $\mathrm{LiF}-\mathrm{RbI}-\mathrm{Li}_{2} \mathrm{CrO}_{4}$. Butlerov Communications. 2014. Vol.38. No.5. P.72-77. ROI: jbc-02/14-38-5-72

[19] A.V. Burchakov, I. K. Garkushin, S.N. Milov. Computer model of phase complex of three-component system LiCl-Li $\mathrm{MoO}_{4}-\mathrm{Li}_{2} \mathrm{WO}_{4}$ Изв. Sarat University. New. ser. Ser. Chemistry. Biology. Ecology. 2018. Vol.18. Vol.4. P.370-376. (russian)

[20] Bertrand Cheynet, Catherine Bonnet, Milan Stankov. GEMINI - DiagPlot: 2D \& 3D ternary phase diagrams. CALPHAD: Computer Coupling of Phase Diagrams and Thermochemistry 33. 2009. P.312-316.

[21] Jinwu Kang*, Baicheng Liu. Stereo 3D spatial phase diagrams. Journal of Alloys and Compounds 673. 2016. P.309-313.

[22] Yuanchang Liang, Hiroyuki Kato, Minoru Taya. Model calculation of 3D-phase transformation diagram of ferromagnetic shape memory alloys. Mechanics of Materials 38. 2006. P.564-570.

[23] V.I. Lutsyk, V.P. Vorob'eva, A.M. Zyryanov, S.Ya. Shodorova. Correction of T-x-y Diagrams for Lead-Free Solders. 16th IFAC Symposium on Automation in Mining, Mineral and Metal Processing August 25-28, 2013. San Diego, California, USA

[24] G.D. Nipan. $\mathrm{p}-\mathrm{T}-\mathrm{x}-\mathrm{y}$ phase diagram of the $\mathrm{Cd}-\mathrm{Zn}-\mathrm{Te}$ system. Journal of Alloys and Compounds 371. 2004. P.160-163.

[25] A.V. Burdakov. Modeling of the phase complex of multicomponent systems involving chromates and alkali metal halides. The dissertation on competition of a scientific degree of candidate of chemical Sciences. Samara. 2016. (russian)

[26] T.T. Basiev. New crystals for lasers on stimulated Raman scattering. Solid state physics. 2006. Vol.47. No.6. P.1354-1358. (russian)

[27] A.V. Lebedev, Synthesis, structural spectroscopic studies of tungstates and molybdates of strontium and barium as active WRC media. Abstract. dis. ...Candidate of Physical and Mathematical Sciences. Krasnodar: The Kuban State University. 2013. 26p. (russian)

[28] I.I. Pubin, R.A. Thomas. Preparation and fabrication of molibdate signale crystals for optical maser studies. J. Amer. Ceram. Soc. 1969. B.49. №2. P.100-102.

[29] A.A. Kaminsky. Laser crystal. Moscow: Science. 1975. P.256.

[30] V.M. Nadiev, Sh.M. Efendiev, V.M. Burlakov. Vibrational Spectra of Crystals with Scheelite Structure and the Solid Solutions on their Basis. Phys. Stat. Sol. (b). 1984. Vol.125. P.467-475.

[31] V.A. Isaev, B.V. Ignatiev, A.V. Lebedev, S.A. Avenesov, P.G. Plautskiy. The Czochralski growth and structural investigations of $\mathrm{Ba}\left(\mathrm{MoO}_{4}\right)_{\mathrm{x}}\left(\mathrm{WO}_{4}\right)_{1-\mathrm{x}}$ solid solution single crystals. Journal of Crystal Growth. 2013. Vol.363. P.226-233. 